\title{
Administrative Service of Civil Servant A Case Study of Civil Service Agency in Majene, Indonesia
}

\author{
Burhanuddin \\ Department of Political Science \\ University of West Sulawesi \\ Majene, Indonesia \\ burhanuddinidris@yahoo.co.id
}

\begin{abstract}
_public service is the task of public organization. This study aims to analyze the performance of regional civil service agency (BKD) in Majene Regency. The research approach used is qualitative analysis. Data collection were taken through observation, indepth interviews and documentation studies. Data analysis techniques consist of data reduction, data display and conclusion. The results showed that the performance of public services is still in the bad category based on indicators of employee responsiveness in meeting the needs and desires of society, responsibility and accountability.
\end{abstract}

Keywords: public service, personnel administration, regional personnel board

\section{INTRODUCTION}

One important dimension in a state government bureaucracy is how officers or employees can provide the best service and quality to the community. Therefore, the government bureaucracy as a front steward in various public interests, has direct responsibility in dealing with various demands and changes in the lives of people that is getting more complex from time to time.

In order to achieve good public service, service standards need to have clear benchmarks that can be used as a reference for action at any state administrator. Good service is how to implement the law as efficiently as possible, scientifically and politically neutral [1].

The implementation of ASN policy and management is based on the principles of legal certainty, professionalism, proportionality, integrity, delegation, neutrality, accountability, effective and efficient, openness, non-discrimination, unity, justice and equality, and prosperity [2].

In this regard, public service providers are ethically obliged to extend the boundaries of public participation in the political process in any way they

Corresponding authors: Burhanuddin can [1]. Public service is a process of meeting the needs and solutions to the various problems that accompany the life of the community. Government has responsibility to provide goods and public services when the community needs or before they ask [3].

A good service will only be realized if there is a) a service system that prioritizes the interests of the community; b) service culture within the organization of service providers, and c) human resources oriented to the interests of service users [4]. In the study of public management, the basic function of management consists of planning, organizing, staffing, leadership, and control [5]. These aspects are fundamental in producing good quality of public services, and it is therefore argued that the lack of these points will affect the results of public services.

Still related to the above public service argument, in order to assess the success of public service, the measurement of the performance of public services becomes important as a form of evaluation for the government.

With regard to the performance of the bureaucracy, several studies show that the root causes of poor public service performance are complicated, with some of its features such as non-transparent and unaccountable procedures [4].

To measure the performance of public services, there are various kinds of instrument and one of them is by using three indicators, namely: a). Responsiveness, b) Responsibility, c) Accountability.

Responsiveness indicators are related to the responsiveness of public service providers to the wishes and needs of the community as service users. The responsibility indicator shows how the public service process is implemented based on the prevailing rules. Finally, the accountability indicator refers to how the public service process is in line with the interests of stakeholders and the norms that develop in society [6].

For every organization, an assessment of performance is an important thing in organizational activity. The results of these measurements can be 
used as a measure of the success of an organization to achieve its goals within a certain period of time [7].

In governance, governments will act to facilitate solutions to public issues and be responsible in ensuring that solutions are consistent with the public interest, either in substance or in the process [8]. Therefore, in the concept of institutional change, the adoption of service standards is a long process or stage through the introduction of new norms to the stage of legitimacy. As an illustration of this is that when the new norm is accepted by the organization members, it then becomes day to day practices [9].

Based on the survey results regarding to the compliance of public services provided by the government of West Sulawesi Province, it received a yellow report card, including Majene districts who also received a yellow report card [10]. The yellow card refers to a poor quality of public services that are managed by government. The results of the survey indicate that compliance of public services in West Sulawesi including Majene Regency is not good enough. This becomes an irony since public service is one of the government's duties in governance.

Public service performance that is not good enough in the scope of Majene District Government one of them occurred in the regional civil service agency (BKD). The performance of public services in the Regional Officers and Training Division of Majene Regency that is not good enough is caused by ineffective and inefficient handling service. Bad and complicated bureaucracy in BKD is caused by the absence of Minimum Service Standards. This is proved by the existence of complaints of employees and teachers in the scope of the Government of Majene District of service handling rank.

\section{RESEARCH METHOD}

This research is conducted by using qualitativedescriptive approach. The informants were chosen purposively, while the informants in this study included: a). Head of BKD Majene, b) Head of General Affairs and Personnel, c) Head of Formation and Personnel Information System, d) Head of Mutation Division, e) Head of Technical Functional Training F) BKD Employee, and g) an agency that takes care of the rank in the Office of Regional Personnel Agency of Majene Regency. Data collection techniques were done through observation, in-depth interviews and documentation studies [11]. Data analysis techniques covered three stages of process namely data reduction, data display, and conclusion [12].

\section{RESULT AND DISCUSSION}

Quality of public service performance is one aspect which can be measured through two indicators, namely efficiency and effectiveness [6]. Based on data on the number of human resources (HR) at the regional civil service agency in Majene Regency, it is as many as 37 people. Based on the education level of employees, the majority of employees have educational background as bachelor level (S1) which accounts for 23 people. Those whose last education was high school education are 8 people and employees with master degree are about 4 people.

The results of this research on the measurement of the performance of public services are based on the measurement of some major dimensions to see the quality of public service in the regional civil service agency in Majene. These selected aspects responsiveness, responsibility and accountability [6] and they will be presented on the following:

\section{a. Responsiveness}

The results showed that the response and responsiveness of BKD employees as public servants is still relatively low. Employee response in providing services often get complaints and shows dissatisfaction. This happened because BKD employees seem very slow to respond the needs of government officials and teachers when they want to work on their promotion. In order to get promotion, civil servants have to work or finish some of the administrative procedures that are managed in the regional civil service agency (BKD).

In addition, the process of obtaining a permit for learning permits often takes a long time to get done. One of the main reason of bad service in BKD office is because the absence of Minimum Service Standards (SPM). This resulted in personnel management service, licensing process for study permit and employee learning tasks often complained by employees and teachers in the scope of local government in Majene. In addition, the lack of comprehensive database of employees contributed to the process of service that becomes complicated.

\section{b. Responsibility}

The poor performance of public services in regional civil service agency $(\mathrm{BKD})$ in Majene is also caused by the absence of Minimum Service Standards. This becomes an obstacle considering the minimum service standard which becomes the standard of service quality that must be implemented by public service providers. In the management of promotion and management of learning permits and learning tasks, there are no fixed procedures related to the duration of the process and how the progress is achieved. This causes employees and teachers who 
access administrative services in the office feel dissatisfied.

\section{c. Accountability}

In fact, the regional civil service agency (BKD) in Majene has not implemented the principle of accountability in providing public services. Based on the results of the research, the low level of accountability is manifested in the absence of certainty regarding the status of administrative management, one of which concerning the management of promotional file and study permit or employee learning tasks. In addition, there is no transparency in financial management in BKD and performance accountability reports (LAKIP) that are not accessible to all levels of society. As a result, to produce or improve the quality of public services, people have to be informed well so that they are more likely to participate in public service delivery by the government. The people need transparency from the government in the implementation of governance especially related to public services.

The results of this research that focused on the performance of public services in the regional civil service agency (BKD) in Majene Regency were produced by using three indicators namely responsiveness, responsiveness and accountability. It indicated that the regional civil service agency (BKD) in Majene has not shown the performance of good public service providers. Public service providers should have responsiveness toward public wants and needs. Moreover, public organizations should provide excellent service to the community. Then as an organization that plays a role in providing public services, BKD office employees carry out duties and responsibilities based on applicable rules. However, the absence of clear rules and procedures (Standard Operating Procedure and Minimum Service Standard) in providing services causes the process of administrative services to be uncertain.

Another aspect is the performance of public services that do not show good public accountability. This aspect should be an underlying principle in the implementation and creation of good governance, where the organization uses the principle of accountability in order to gain public trust.

Based on the above discussion, this is certainly an irony in public service, as service providers should apply these indicators. The ideal performance of the public organization is when it is able to provide satisfaction to the recipients in the context of public service delivery. Moreover, the regional civil service agency public must provide service and be able to accommodate the need of certainty in the process of job promotion for government officials and teacher in Majene Regency. In other words, BKD should respond quickly and effectively to the public interest [6].

Still associated with this concern, the absence of minimal service standards and administrative service procedures cause the organization's performance to be ineffective and efficient, where the performance of an organization is important as a form of evaluation for improvement of organizational performance [13].

\section{CONCLUSION}

The performance of public service in the regional civil service agency (BKD) in Majene Regency is not optimal, due to the lack of responsiveness to the public desire. ineffective implementation of standard operational procedure and low levels of accountability are also the cause of low performance of public services.

\section{REFERENCES}

[1] J.V Denhardt and R.B Denhardt, "The New Public Service" (Pelayanan Publik Baru), Translator Saut Pasaribu, Kreasi Wacana, Bantul. 2013

[2] Law Number 5 Year 2014 on State Civil Apparatus

[3] A.G.Subarsono, "The Efficient, Responsive, and Non Partisan of Public Service”.'(Pelayanan Publik Yang Efisien, Responsif dan Non Partison), Gadjah Mada University Press, Yogyakarta. 2006

[4] Ratminto and Winarsih. "Management Services Conceptual Model Development, Implementation of Citizen's Charter and Minimum Service Standards", (Manajemen Pelayanan Pengembangan Model Konseptual,Penerapan Citizen's Charter dan Standar Pelayanan Minimal), Pustaka Perlajar, Yogyakarta. 2009

[5] G. Dessler,Human Resource Management (Manajemen Sumber Daya Manusia), Jakarta. PT Indeks. 2010

[6] Lavine, Charles H. Public administration chalenges choices, consequences, glenview. Scottforeman/little browhigher education: Lilionis. 1990

[7] Keban, Yeremias T. Local Government Performance Indicators: Management and Policy Approach, One Day Seminar on Public Sector Organization Performance, Policy and Implementation. (Indikator Kinerja Pemerintah Daerah :Pendekatan Manajement dan Kebijakan, Seminar Sehari Kinerja Organisasi Sektor Publik, Kebijakan dan Penerapan). 20 Mei.Yogyakarta. MAP-UGM. 1995

[8] J.V.Denhardt dan R.B. Denhardt, "The New Publik Service", M.E. Sharpe, New York. 2003

[9] E.A.Purwanto, "Strategy for Implementing Service Standards for Bureaucratic Reform, in "Bureaucratic Reform, Leadership and Public Service" (Strategi Penerapan Standar Pelayanan Untuk Reformasi Birokrasi, dalam "Reformasi Birokrasi, Kepemimpinan dan Pelayanan Publik) (Editor Agus Pramusinto and Erwan Agus Purwanto), Gava Media, UGM-MAP-UGM, Yogyakarta. 2009

[10] Ombudsman RI, "Public Service Compliance Survey (Survey Kepatuhan Pelayanan Publik)". 2017

[11] M.B. Miles, and A.M. Huberman, "Qualitative Data Analysis: An Expanded Sourcebook,", SAGE Publication, Inc, New York. 1994

[12] R.K. Yin, "Case Study Research: Design and Methods, $4^{\text {th }}$ Eds. SAGE Publication Inc. Thousand Oaks, California. 2009

[13] McDonald and Lawton . "Human Resource Management" (Manajemen Sumber Daya Manusia). Terjemahan. Jakarta. PT Gramedia Pustaka Utama. 1977 